\title{
Local Marriage System of Boti Community Depicted Through its Speech Ritual
}

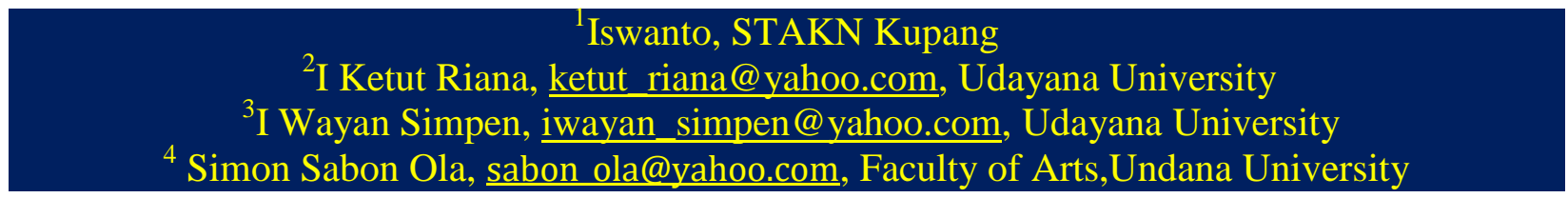

\section{*Corresponding Author: iswantoyohanes@rocktmail.com}

Received Date: 02-05-2018 Accepted Date: 7-05-2018 Published Date: 04-01-2019

Abstract - Marriage system in the indigenous trust describes the relationship of supernatural effect on family kinship in the community. Such the relevance is the primary identifier and the identity of the diversity of the Indonesian nation. It is inevitable that a cultureas a pillar of diversity is a buffer for entering the era of multicultural and globalization. Values of Humanist is the power of social relation among individuals in the community groups. This paper describes the characteristic of marriage in society of Boti in East Nusa Tenggara who hold the original trust Halaika. The results shows behaviors that indicate homage to supernatural of Uis Pah (Ruler of the Earth), Uis Oe (Ruler of Water) and Uis Neno (Ruler of Heaven) in a series of marriages that is rich of value and meaning.

Keywords: Halaika, Uis Neno, Uis Pah, Uis Oe.

\section{Introduction}

Cultural phenomenon can be observed in a context that has been developed over time to form a system of culture and reflects in the ideas, values, norms, and regulations. Contextually, cultural phenomenon can be verbal or nonverbal, generated from generation to generation, forming a visible social cognition and behavior. In terms of perception, it shows relationship of language and culture in a society that still adheres to the values of their faith (Danesi 2004: 138139). Conceptually, speaking is a hierarchical experience that is so closely to meaning and value. Ritual speech as oral literature implied in it is social cognition system of its society (Sharifian, 2011: 4-6). At this level, the language as a means of forming the idea of reconstructing the individual's perception of cultural meaning, both in microcosm and macrocosm. The nature of the language becomes media to understand and explain the cultural reality in society (Fox, 2006: 146).

Cultural reality is seen based on paradigm of linguistics embodied in related to the systematic signs, forming perception, represented in context, and at the highest level as a description of the ideology of community groups (Craig, 1998: 375). At this level,the language 
as cultural expression scrutinizes the meaning at the level of signs assuming mutually associative ideas in related to one another. The relevance also occurs at the level of social relationships, values and cultural norms. In the philosophy of language, it is associated with cognitive-realist paradigm in the view of Plato (Soames 2010: 123).

The above statement becomes the point to prompt the author to analyze the unique ritual speech of Boti community. Ritual speech as part of cultural rituals contains religious values, which includes marriage system. Supernatural concept is seen as something that is very high, in terms of the Giver of life, and the Ruler of life, meanwhile man is considered very low, so that man cannot reach it (transcendential). In fact, the concept of the supernatural for Dawan society (including Boti community) can only be mentioned with unique and special attributes, like uisneno, uispah, and uisoe (Widiyatmika, 2008: 71, 72).

The values of the local culture are arranged neatly, present a series of powerful meanings that cannot be influenced by modernity. Multicultural and globalization as a new paradigm that unites people and cultures into a pluralistic perception insists demands on cultures around the world. With diversity which becomes identifier as shown in Boti societyis expected to bring the Indonesian people not only to run into global rhythm but also show its typical characters in full competitive world.

Thus, this article examines and describes local marriage system of Boti community illustrated through its ritual speech. In related to the research problems, it used descriptive qualitative method with phenomenological approach as a basic philosophy in this article. Phenomenology as part of philosophy of cognitive-realism underlying its concept on the experience of interacting in social environment, restricted-cultural norms and values regardless of outside distortion influences. In this way, then phenomenology approach seeking principles of perception reading as a system of cognition. Therefore, the concept of phenomenologyis related to philosophy and hermeneutics (Gallagher, 2008: 6).

\section{Research Methods}

This research is a descriptive qualitative study which is rooted in Phenomenology. Theoretical Framework based on Course de Linguistique Generale. De Sausure describes language as a sign system. Signs are combinations of concepts and acoustic images (De 
Saussure, 1993:147) and sign is the unity between two inseparable aspects of each other: signifiant (signifier) and signifie (signified); signifiant is the formal aspect or sound of the sign, while signifie is the aspect of meaning or conceptual. Signs that form the langue are concrete as a result of collaboration between signifier and signified (De Saussure, 1993:193). In this case, sign in the level of langue is in the form of complex system. For example the word arbor, in Latin is used to name the concept of "tree". Arbor can be categorized as a sign, only if it refers to the concept of "tree", this means the whole idea coming from the sensory part that makes an idea of the whole sign (De Saussure 1993:145-147). Furthermore, de Saussure argues that the signifier (signifiant) is essentially auditive, takes place in time and has the same characteristics as time.

In further analysis, Beagrande (1980:39-45) explains that textual world in a discourse is a series of thought (node) syntactically centered on a head. These Nodes also relate associatively to form an intertextual relationship known as a network (link). In data collection, an open and depth interview is conducted through techniques such as (1) recording, (2) elicitation, (3) In-person interview, and (4) notes. In qualitative research, data analysis is an inductive process developed from facts (data) to a keen abstraction. It uses the principles in Hermeneutics which are constructed under the phenomenological interpretative principles (Spinelli, 2005:8).

\section{Result and Discussion}

Geographically, Boti village is located in Kie Sub-district, South Central Timor Regency (TTS), East Nusa Tenggara (NTT). Boti area is $17.69 \mathrm{~km} 2$ divided into four hamlets namely, Boti A, B, C, and D. Boti A and B are categorized as Boti In, whereas Territory Boti C and D are categorized as Boti Out. The two categorized areas are separated by a river Neo Bet Pena. In the area of Boti In (Boti A) is the administrative center of the kingdom (the kingdom of Boti/sonaf) and administrative government (village office). Boti community life is customarily headed by Usif as a tribal leader. Various activities taken place in the area should be with the priority of the king. King plays to regulate various aspects of citizens' lives from birth, marriage and death. The Usif has a social and moral responsibility for the welfare and goodness of his citizens. Therefore, Usif will not hesitate to intervene in the lives of his citizens who violate customary rules. All done for the goodness and peace of the citizens. To run the task and role, Usif 'king' assisted by a 
commander (mеo). Meo's task is to secure the area/neighborhood and village of Boti kingdom as a whole from the various danger that threaten them, mainly attack the enemy from the outside. Each Meois placed in each border kingdom. In the Western region is ruled by meofeto (commander) headed by BernardusBenu and meomone (the vice commander) by Bota Benu in the Eastern region. Another task is to secure the meo king's order and as the king's right hand. If there are activities in the kingdom of dealing with outsiders, it should be coordinated by meo. BesideMeo, there is also lopolopo, as the assistant of administrative areas. They are authorized to implement rules of the kingdom at the regional level. Thus, in case of problems at the regional level, the lopo coordinates them with Usif to immediately take in necessary action. In sonaf environment, there are also the waiters of kingdom. They consist of clans Neolaka, Tefamnasi, and Boentekan. Their jobs are to provide and arrange supplies of food and drink in the Palace. They are also taking care of and maintaining the gardens and livestock of the king (Rumung, 1998: 1-14).

The process of birth, marriage, house moving and having children, is a cycle of life. Marriage of Boti people does not apply dowry system. Marriage process starts from bride family carrying a bottle of gin and one of ancient coins. The bridegroom receives the bottle of gin and coin as sign of approval. Marriage process does not stop at this stage, but it takes many years to have a family party.

Marking attitudes and behavior are not limited to everyday activities. Especially for women, weaving and plaiting is closely related to the marriage process. Women who produce good woven clothes are easily to get a mate. Parents of men are usually seeking women by considering with those who weave well. This is seen when women are in crowded places such as markets and meetings. Women who are skillful in weaving are considered to have good taking care of the household later.

The new family is required to live independently to build their own home, separated from both parents. It is expressed in the concept of umenanan 'in house'. New home marks the beginning of a new family life. Husbands have to work in the fields and raising livestock. While women weave and plait. The fields which produce much crop and well maintained livestock symbolize supernatural of pahmanifu blessing the new families. Similarly with cotton run into 
yarn and cloth, or make oko and other plait well signifies harmony of human relationships with the supernatural of pahmanifu.

The process of giving a birth smoothly is a symbol of the marriage agreement from uisneno. Meaning of lingual forms honis 'live' on the proposition of uisnenofekohonis 'uisnenogives life' is defined as life associated with their soul. In contrast to monit 'life' associated with life and everyday activities. The distinction of meaning explains public perception on everything that has high value of culture. Life is defined such that the attitude and behavior as well as elements involved in the elucidation treated differently according to their meaning level.

The birth of a child as a sign of life, celebrated with a traditional feast. This party is the last stage of the wedding in Boti community.

The activity implementation can be seen through the ritual speech Baan MahMahFetMonet. Ritual speech of Baan FetMahMah Monet is the customary pledge between parents of bride with the parents of bridegroom to hold a traditional wedding party shortly after the family has a child. Data speech exposed as below.

\section{Transcription}

BAAN MAH FET MAH MONET

Nua ki tabu $i$

Tok bale' teta'

Tok ume teta'

Natuin hai nua kae

Bae feto bae mone hai lomin

Es nane maminai himonit

Atoni ho lene nanes

Ho tua' namak

Hai amfeto hom banit tenu muhin

Lunat names

Mes au ok au bae'

Hai mieku fani

Alkai malin okoke

\section{Translation}

\section{CUSTOMARY PLEDGE}

You two, this time

Sit down on your own

Sit down at your own home

Because we are both together

The desire of having nephew and niece

Therefore, find your own life

Man, your garden is productive

Your palms provide a lot of yield

Our daughters, smart in weaving

Plait well

Later, I and my nephew

We meet again

We have fun together

To reveal the signifier system of attitudes and behavior on ritual speech of Baan FetMah, it needs to be analyzed the correlation between syntagmatic and paradigmatic beforehand. 
Baan MahFetMah Monetritual speech consists of three dimensions, the First line, dimension I begins with a noun phrase nuaki 'you two' which attached with the adverb phrase tabui 'this time'.

Nuakitaboo i (TRP 3.2.1)

two you today

'You two, now'

Line I first dimension is then followed by a form of parallelism on the second line and line II first dimension, as the data below.

Tok

bale 'teta' (TRP 3.2.2)

Sitting on his/her own place

'Sitting on their own'

Tok ume teta' $($ TRP 3.2.3)

sitting in his/her own home

'Sitting at their own home'

Pararelism form on the lines II and III, is a characteristic of poetic lingual which reflects the extension of the principle of opposition binary (Fox, 1984: 280-282). In terms of phonetic, they have two lingual forms with the same phonemes / $\mathrm{t} / / \mathrm{o} / / \mathrm{k} /$ and / t / / e / / / / a / / k /, which express sound harmony and also the lingual forms/ $\mathrm{u} /$ / $\mathrm{m} /$ / e / and / b / / a / / / / e /. In terms of semantic parallelism, tokbale teta and tokumeteta refer to the same meaning that mean living separately with parents. In cognition, human emphasize on meaning by repeating a sentence in the form of other disclosures. The meaning harmony characterized by tok 'place' that is aligned with ume 'home'. Marking parallelism semantics associated with standard social context symbol to explain typical terms in the culture of the society (Fox, 1984: 74).

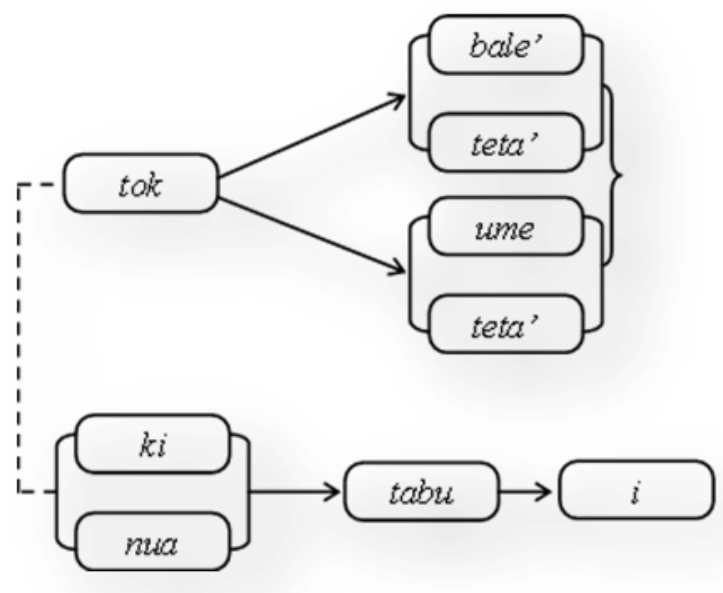


Cognitive Map 1 illustrates paradigmatic relationship between the lingual form kinua'we two' with an intransitive verb tok 'sit'. This relationship explains the function of the subject (kinua) with verbs (tok). Entanglement relationship between kinua and the verb tok becomes important because the speaker in the concept of mental wants to explain the whole ritual utterances through the concept. Topics disclosed in the beginning to later described by lines and further dimensions.

The lingual form tok 'sit' attached with locative adverb bale 'teta' own place 'and umeteta'own home 'becomes a single topic that paradigmatically controls logic of the ritual speech Baan MahFetMah Monet.

The next one is line IV first dimension has relationship with the line V dimension I, which line IV is described by line $\mathrm{V}$, the lines seen in the data below.

Natuin nua hai kai (TRP 3.2.4)

because we two us

'Because we are both together'

Bae feto bae mone hai lomin (TRP 3.2.5)

nephews nieces we would

Desire of nephew and niece'

Line IV begins with a conjunction natuin 'because' which is attached to the first person plural pronoun $h i$ 'we'. Personal pronoun hai'we' is further illustrated by the adverb noa 'two' and then attached to the first person plural pronoun kai 'we' that functiones as a complement.

Line V describes line IV with baefeto 'nephew' and baemone 'niece'. The uniqueness that appears on lines IV and V is that the speaker, in this case the uncle of the bride does not assert directly with both couple, or a new family, but with a nephew and niece. Politeness of language used in a ritual event places emphasis on the values of religiosity in the ritual event.

Moreover, the implicit meaning of the use of baefeto 'nephew' and baemone'niece' by speakers signaling family relationships between parents of bride and parents of groom. In the event of this speech, the speaker does not involve the language of our nephew and your daughter, but involving a language that unites the two family groups. 
In syntagmatic and paradigmatic, dimension I is depicted on a cognitive map 2 below.

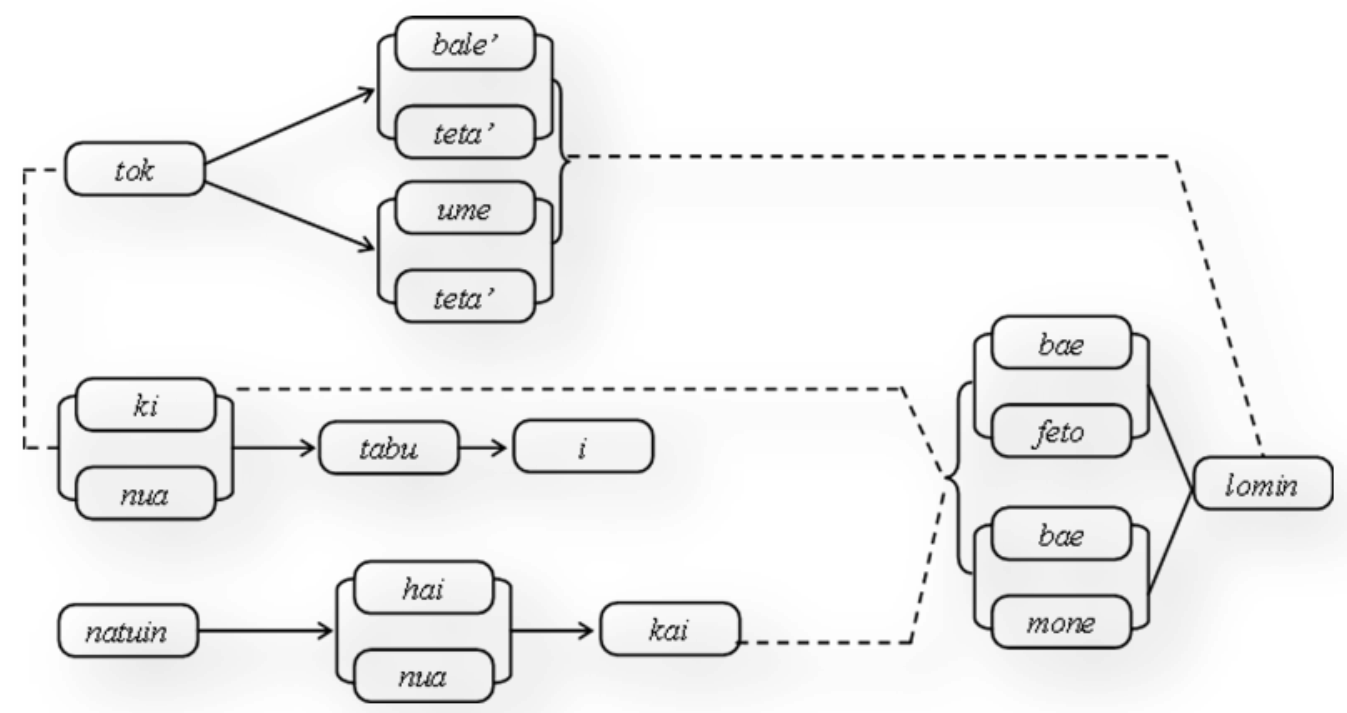

The next section, line I dimension II, characterized by the concept maminalhimonit 'find your own life'. Paradigmatically, the concept relates to concept of tok bale teta'sitting place of their own', tokumeteta 'sit at own home' and lomin 'willingness'.

Line I dimension II can be seen in the data in the speech below.

Es nane maminai hi monit (TRP 3.3.1)

therefore find you alive

'Therefore, find your own life'

Besides being attached to the previous dimension,concept of maminalhimonit 'find own life', becomes a topic for a whole dimension II. This can be seen in the data below.

Atoni ho lene names (TRP 3.3.2)

man you garden nice

'Man, your garden is good'

Ho tua 'Namak (TRP 3.3.3)

you palm tree contains

'Your palm tree is productive'

Hi amfeto hombanit tenu Muhin (TRP 3.3.4)

we daughter you work weave smart

'Our daughter, clever at weaving' 


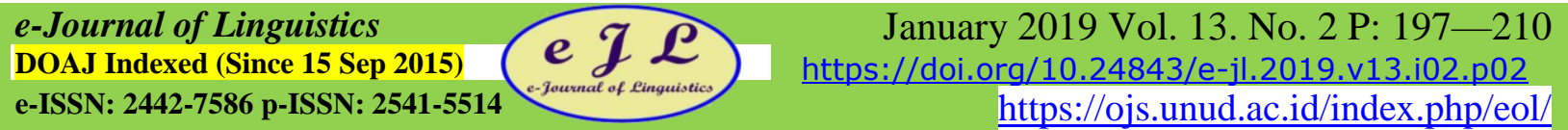

Lunat names (TRP 3.3.5)

Plait good

'Well plaiting'

Paradigmatically, concept of maminalhimonit 'find own life' has the following attributes (1) lene names' nice gardens' (2) tuanamak 'palm tree contains' (3) bonittenumuhin' well weaving'(4) lunat names' nice plait'. Syntagmatic relations and paradigmatic dimension II depicted on a cognitive map 3

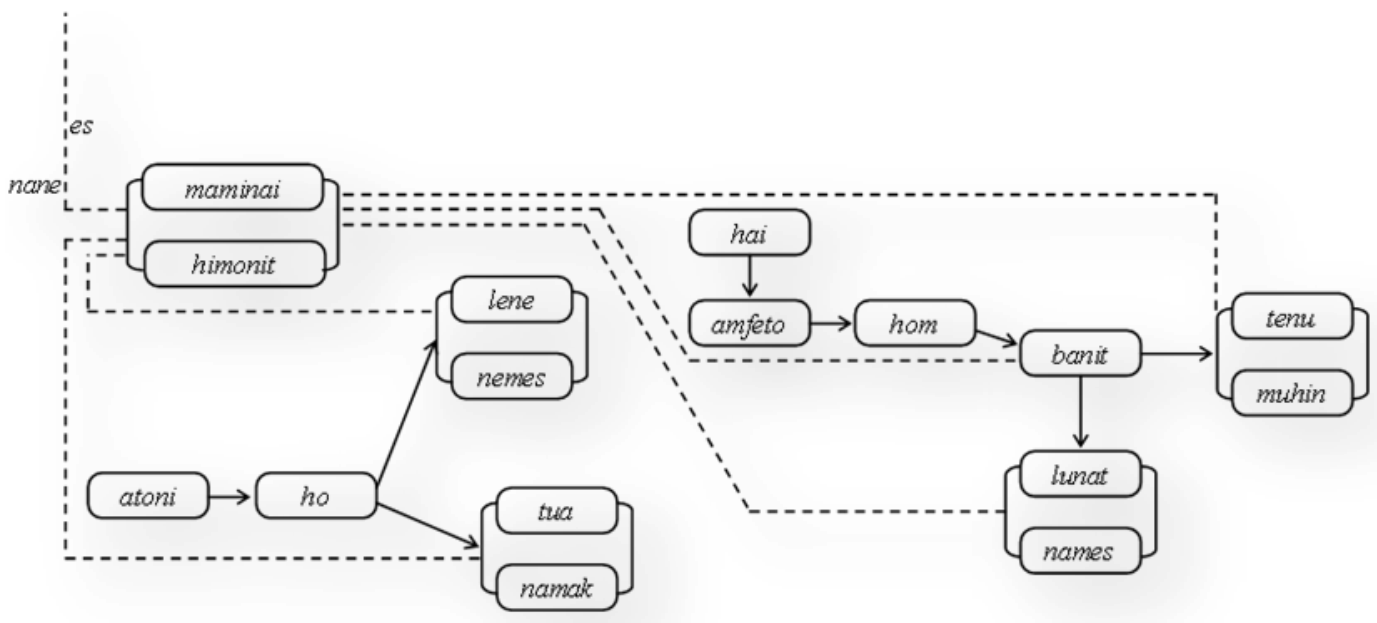

The next part of the third dimension, as a whole can be seen in the data glossing below.

Mes au ok au bae'(TRP 3.4.1)

later I with nephew my

'Later I am (will be) with my nephew'

Hi mieku fani (TRP 3.4.2)

we meet again

'We met again'

Alkai malin okoke (TRP 3.4.3)

all we happy together

'We have fun together'

Dimension III ritual speech Baan MahFetMah Monet focused on line I, namely in the form of lingual $a u$ 'I'. Marking of attitudes and behaviors found in the form of lingual miekufani'reunited' which is paradigmatic attached to lingual form malinokoke'have fun together'. This lingual form interpreted as a wedding party that will be held shortly after the new couple has a child. 
Syntagmatically and paradigmatically, dimension III of speech ritual Baan MahFetMah Monet, described the cognitive map 4, below.

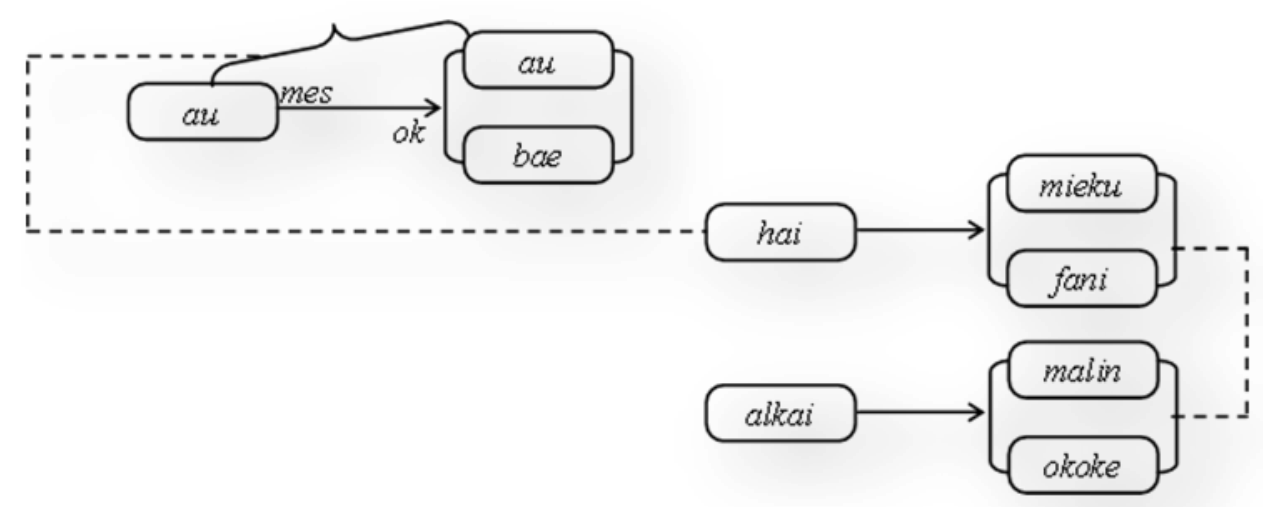

Overall, value and meaning of marriage ritual speech MahFetMah Monet can be described as follows:

Tok bale teta 'sitting at place of their own', tokumeteta 'sit at home of their own'. This concept explains that marriage is perceived not only as a sacred relationship building but also as togetherness of a man and a woman to arrange good life. In this case, the concept tokbale teta and tokumeteta corresponds to the concept of monitnaleko 'good life'

Ma minai himonit 'find your life' cognitive map 1-4 explains that this concept is explained paradigmaticallywith attributes such as (a) lene names' nice garden '(b) tuanamak'productive palm tree' (c) bonit tenu muhin 'smart weaving work '(d) lunat names' good plait. Those mean that the Boti people living by working hard and not by cheating, stealing, and doing work that is contrary to community law. Abundant crop is also obtained from the value of religiosity of each individual. Individualswho are close to pahmanifu, have a close relationship, even to unite with nature, being able to identify signs of nature well, so that the crops will be abundant.

Mieku fani 'reunited', this concept becomes important in ritual speech Baan Mah Fet Mah Monet, due to a wedding party that becomes the highlight of the new marriage will be done after the couple has their first child. It underlies attitude of Boti society that respects and appreciates the supernatural. Uisneno as the owner of life authority, placed in a very high position, even inaccessible, so that humans do not have the authority to assess that marriage is blessed by uisneno. The birth of a child as a symbol of life, is proof of blessing of uisnenoto the marriage. If the obstacles encountered in giving a birth process, then the family of the husband will hold 
ceremony naketi 'recognition' of something considered to be hindering harmonious relationship to uisneno. Boti community inspires their space as a space of action, every event in life, such as birth, marriage, death, even things that are more specific, always linked to the religiosity.

\section{Novelties}

The novelties in this article are (1) baan mah fet mah monet 'customary pledge' ritual data. The data is categorized as a novelty because it is sourced from oral data that has never been transcibed into writing. (2) The theory used is anthropological linguistics combined with theory of sign system by de Saussure. The theory used produce cognitive maps to analyze a sign. (3) The method used is qualitative with Husserlian's phenomenology research paradigm. The data of this study is qualitative, which must be analyzed continuously.

\section{Conclusion}

Local marriage of Boti community explains the value of the cult as a cultural identifier. This value is interpreted as a symbol of the house as the union of the couple. When it is occupied then the husband must work hard in the garden and wait for harvest. It reflects a husband as breadwinner for his family. When the garden begins to reveal harvest then that bodes uispahmanifu (ruler of the earth and water) bless to the family. If the garden does not reveal harvest, the family has to carry out the ceremony of confession called naketi. When class of the household endowed with a soul or a child or descendant is a sign of blessing of the highest authorities, namely uisneno. If the family does not have a child within a certain time then held a traditional confessions known as naketi.

This marriage cycle ends with the wedding after all stages are reached. It indicates that this family will continue blessed by uisneno, the Giver of life and uispahmanifu, the savior of life.

The whole article provides an overview of the cultural wealth of this country, which we should have known and survived to be a value of differentiator in the global world. 


\section{References}

Danesi, Marcel (ed). 2004. A Basic Course in Anthropological Linguistic. Toronto: Canadian Scholar's Press inc.

De Saussure, Ferdinand. 1993. Pengantar Linguistik Umum.Terjemahan buku Course de Linguistique Generale, oleh Kridalaksana, Harimurti. Yogyakarta: Gajah Mada University Press.

Dhavamony, Mariasusai. 1995. Fenomenologi Agama. Terjemahan buku Phenomenology of Religion. Yogyakarta: Kanisius.

Duranti.Alesandro. 1985. Sociocultural Dimension of Discourse. Dalam Handbook of Discourse Analisys, Vol. 1.Academic Press

Duranti.Alesandro. 1997. Linguistic Anthropology. Cambridge: Cambridge University Press.

Eco, Umberto. 1984. Semiotics and the Philosophy of Language. Basingstoke: Macmillan.

Eco, Umberto. 2009. Teori Semiotika. Diterjemahkan dar iA Theory Of Semiotics oleh Inyiak Ridwan Muzir. Yogyakarta: KreasiWacana.

El-Aswald, El-Sayed. 2002. Religion and Folk Cosmology: Scenario of the Visible and Invisible in Rural. London: Greenwood.

Eriyanto. 2005. Analisis Wacana: Pengantar Analisis Teks Media. Yogyakarta: LKiS.

Errington, Joseph. 1982. Speech in The Royal Presence: Javanese Palace Language, dalammajalah Souteast Asia Program, Volume 34.

Evans, Vyvyan, dkk. 2010. The Cognitive Linguistics Enterprise: an overview.

Faisal, Sanapiah. 1990. Penelitiah Kualitatif: Dasar-dasar dan Aplikasi. Malang: YayasanAsah, Asih, Asuh

Flick, Uwe. 2004. Triangulation in Qualitative Research. Dalam A Companion to Qualitative Research.London: Sage.

Foley, William A. 1997. Anthropological Linguistics: An Introduction. USA: Blackwell

Fox, James. 1986. Bahasa, Sastra, dan Sejarah; Kumpulan Karangan Masyarakat Pulau Roti. ILDEP.

Fox, James. 2006. Memories of Ridges-Poles and Cross-Beames: The Categorical Foundations of a Rotinese Cultural Design, dalam Fox, James J. (ed), Inside Austronesian Hauses: Perspective on Domestic and Disigns for Living. Cambera: ANU

Gallagher, Shaun dan Dan Zahavi. 2008. The Phenomenological Mind: An Introduction to Philosophy of Mind and Cognitive Science. London:Routledge. 
Rumung, Wens John. 1998. Misteri Kehidupan Suku Boti. Kupang: YayasanBoti Indonesia.

Sharifian, Farzad. 2011. Cultural Conceptualisations and Language: Theoretical Framework and Applications. Amsterdam: John Benjamins Publishing Company

Sibarani, Robert. 2004. Antropolinguistik. Medan: Poda.

Soames, Scott. 2010. Philosophy of Language. UK: Princeton University Press.

Spinelli, Ernesto. 2005. The Interpreted World: An Introduction to Phenomenological Psychology. London: SAGE.

Widiyatmika, Munandjar. 2008. Kebudayaan Masyarakat di Bumi Cendana.Kupang: Pusat Pengembangan Madrasah.

\section{Acknowledgments}

The author wishes to thank all those who have given valuable contributions to this research so that the results can be disseminated through publication, especially to the examiners: Prof. Dr. Aron Meko Mbete, Prof. Dr. I Ketut Darma Laksana, M. Hum, Prof. Dr. Drs. Ida Bagus Putra Yadnya, M.A., Prof. Drs. I Made Suastra, M.A., Ph.D., Prof. Dr. Made Budiarsa, MA. for their advices to deepen the analysis and presentation of appropriate research results. 


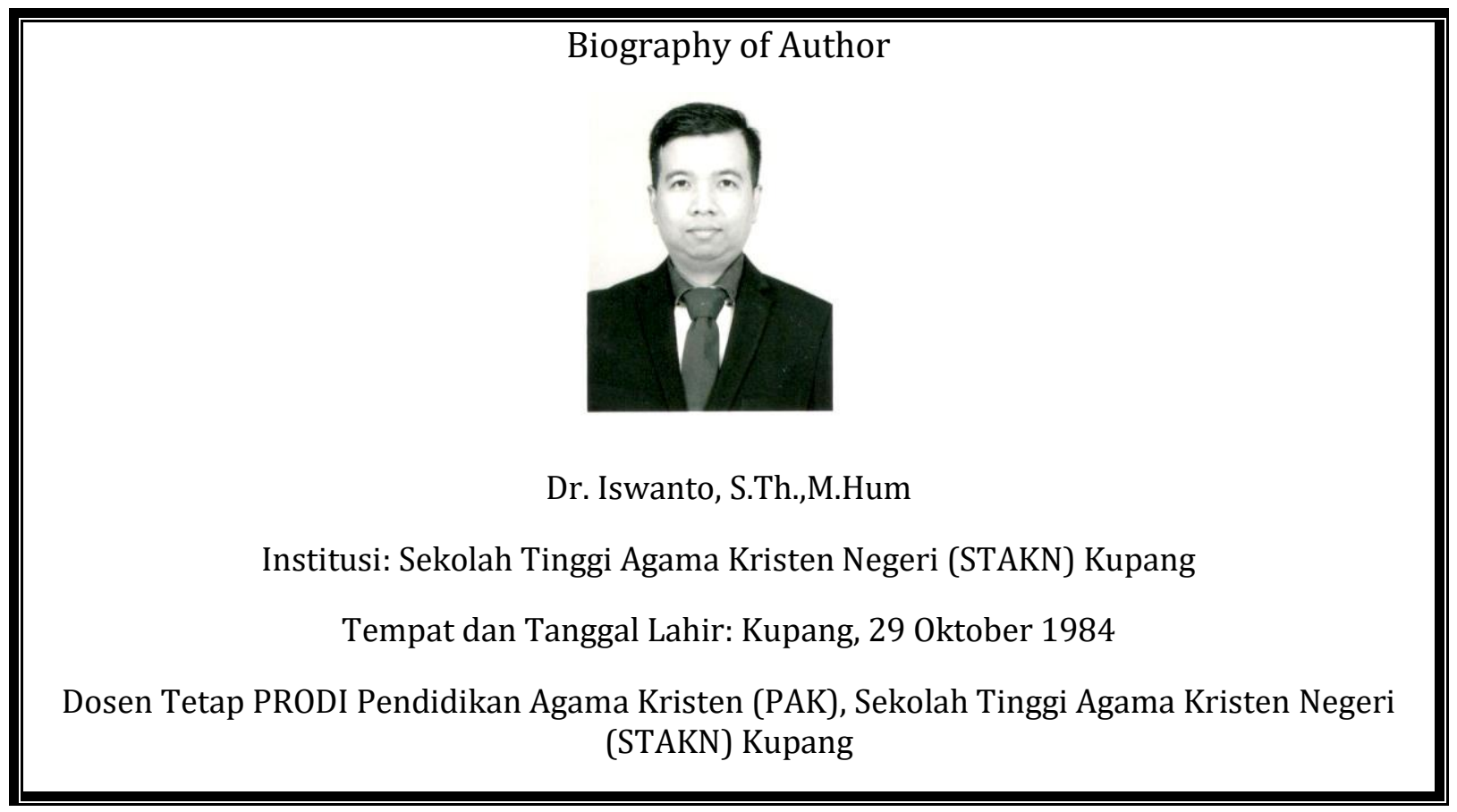

